\title{
Sekresi Asam-asam Organik oleh Aspergillus niger YD 17 yan Ditumbuhkan dengan Batuan Fosfat
}

\author{
Secretion of Organic Acids by Aspergillus niger YD 17 that Grown with Rock Phosphate \\ Yudi Sastro $^{1 *}$, Donny Widianto ${ }^{2}$, Dja'far Shiddieq $^{2}$ \\ ${ }^{1}$ Balai Pengkajian Teknologi Pertanian, Jakarta *Penulis untuk korespondensi \\ ${ }^{2}$ Fakultas Pertanian, Universitas Gadjah Mada, Yogyakarta.E-mail: yudis_bkl2001@yahoo.com
}

\begin{abstract}
Information on ability of Aspergillus niger to secrete organic acid is important in using $A$. niger as phosphate rock-solubilizing microorganism. This research was aimed to examine the ability of $A$. niger YD 17 secreting organic acid when it was grown with phosphate rock. An A. niger YD 17 was obtained from Laboratory of Microbiology, Faculty of Agriculture, GMU. The phosphate rock used was Christmas Island phosphate rock. Organic materials consisted of tapioca waste industry, rice bran, and starch. The study was conducted in Pikovskaya liquid medium and soils that were taken from Jasinga, Banten, West Java (ultisol) and Karang Jati, Ungaran, Central Java (inceptisol). The type and level of organic acid production were determined using high performance liquid chromatography (HPLC). The results indicated that $A$. niger YD 17 was able to secrete organic acid when it was grown with phosphate rock. The level of organic acid in the Pikovskaya liquid medium reached $255.7 \mu \mathrm{g} . \mathrm{ml}^{-1}$, whereas in the soil reached $2992.5 \mu \mathrm{g} . \mathrm{g}^{-1}$. Malate dominated organic acid in the Pikovskaya liquid medium, while in the soils dominated by oxalate. The type and level of organic acid secreted by $A$. niger YD 17 were influenced by carbon and phosphorus sources, concentration of inoculums, and characteristic of the soils.
\end{abstract}

Key words: organic acid, Aspergillus niger, phosphate rock

Diterima: 11 Januari 2006, disetujui: 13 Juni 2006

\section{Pendahuluan}

Pada kondisi optimal $A$. niger mampu mengkonversi glukosa menjadi asam sitrat dan telah dilaporkan memiliki kemampuan mensekresikan asam-asam organik, khususnya asam sitrat (Legisa dan Gradisnik-Grapulin, 1995; Ul-Haq et al., 2002; Ali et al., 2002; ElHoli dan Al-Delaimy, 2003). Kemampuan A. niger untuk mensekresikan asam organik tersebut, khususnya asam sitrat, telah mendasari para peneliti untuk mengembangkannya sebagai agensia pelarut batuan fosfat, guna memasok fosfat (P) untuk tanaman (Salih et al., 1989; Goenadi dan Saraswati, 1993; Goenadi, 1996; Goenadi et al., 1999, 2000; Widiastuti et al., 2000; Atmodjo, 2000).
Namun demikian, efektivitas A. nige melarutkan fosfat memiliki variasi sanga lebar. Elfiati et al., (1999); Zapata dan Roy (2004) melaporkan pada skala laboratorium, $A$ niger mampu melarutkan trikalsium fosfa berkisar dari 37,5 hingga 87,6 ppm. Thomas $e$ al., (1985) melaporkan tingkat pelaruta trikalsium fosfat oleh A. niger berkisar 42, hingga 72 ppm. Asmarlaili et al., (1995 melaporkan tingkat pelarutan trikalsium fosfa oleh $A$. niger berkisar 107,4 hingga 265,7 ppm sedangkan Ernita (1998) melaporkan tingka pelarutan trikalsium fosfat mencapai $829 \mathrm{ppm}$ Aspergillus niger juga terbukti mamp melarutkan aluminium fosfat berkisar 2 hingga 265 kali dibandingkan kontrol tanp inokulasi A. niger (Goenadi dan Saraswat) 1993). 
Lebarnya variasi kemampuan pelarutan fosfat tersebut disebabkan oleh berbagai faktor yang mempengaruhi biosintesis dan sekresi asam organik oleh A. niger. Sanjay dan Sharma (1994) serta El-Holi dan Al-Delaimy (2003) melaporkan bahwa jenis dan jumlah asam organik yang disekresikan oleh $A$. niger nyata dipengaruhi oleh sumber karbon, logam-logam, dan $\mathrm{pH}$ medium.

Dalam rangka mengoptimalkan pemanfaatan $A$. niger sebagai agensia pelarut batuan fosfat, informasi mengenai sekresi asam organik oleh $A$. niger pada saat digabungkan dengan batuan fosfat masih sangat diperlukan. Penelitian ini bertujuan untuk mengetahui kemampuan dan faktor-faktor yang mempengaruhi sekresi asam organik oleh $A$. niger, apabila jasad tersebut digabungkan dengan batuan fosfat.

\section{Metode Penelitian}

\section{Batuan fosfat}

Batuan fosfat yang digunakan dalam penelitian ini adalah batuan fosfat Christmas Island lolos saringan 100 mesh. Batuan fosfat diperoleh dari PT. Petrokimia Gresik, Jawa Timur. Karakteristik batuan fosfat disajikan pada Tabel 1.

\section{Bahan organik}

Bahan organik yang digunakan adalah onggok (limbah pabrik tapioka), sekam, dan pati. Onggok diperoleh dari industri tapioka di desa Karang Kulon II, sedangkan sekam diperoleh dari perusahaan penggilingan padi "Sari Bumi" yang berada di desa Sidomulyo, masing-masing berada di kecamatan Salaman, Magelang, Jawa Tengah. Sekam dan onggok dihaluskan dan disaring menggunakan saringan 100 mesh. Pati yang digunakan adalah pati murni (pure analysis) dari Merck. Karakteristik bahan organik disajikan pada Tabel 2 .

Tabel 1. Karakteristik batuan fosfat Christmas Island

\begin{tabular}{lr}
\hline \hline Sifat dan kandungan & \\
\hline \hline $\mathrm{pH}-\mathrm{H}_{2} \mathrm{O}(1: 2,5)$ & 8,20 \\
$\mathrm{P}_{2} \mathrm{O}_{5}$ terlarut air $\left(\mu \mathrm{g} \cdot \mathrm{g}^{-1}\right)$ & 783,60 \\
$\mathrm{P}_{2} \mathrm{O}_{5}$ terlarut sitrat $2 \%(\%)$ & 6,52 \\
$\mathrm{P}_{2} \mathrm{O}_{5}$ total $(\%)$ & 32,13 \\
$\mathrm{CaO}(\%)$ & 49,20 \\
$\mathrm{MgO}(\%)$ & 0,26 \\
$\mathrm{Al}_{2} \mathrm{O}_{3}(\%)$ & 1,52 \\
$\mathrm{Fe}_{2} \mathrm{O}_{3}(\%)$ & 4,91 \\
$\mathrm{Mn}_{2} \mathrm{O}_{3}(\%)$ & $\mathrm{tt}$ \\
$\mathrm{Zn}_{\left(\mu \mathrm{g} \cdot \mathrm{g}^{-1}\right)}$ & $\mathrm{tt}$ \\
Kadar air $(\%)$ & 1,12 \\
Kehalusan (mesh) & $>200$ \\
\hline \hline
\end{tabular}

Ket : $\mathrm{tt}=$ tidak terdeteksi

Tabel 2. Karakteristik kimia bahan organik

\begin{tabular}{cccc}
\hline \hline Sifat dan Kandungan & Onggok & Sekam & Pati \\
\hline \hline C-total (\%) & 43.20 & 45,10 & 45,93 \\
N-total (\%) & 0,77 & 0,70 & td \\
C/N & 56,10 & 64,43 & td \\
$\mathrm{P}_{2} \mathrm{O}_{5}$-total (\%) & 0,93 & 0,69 & $\operatorname{td}$ \\
$\mathrm{K}_{2} \mathrm{O}$-total (\%) & 0,85 & 0,28 & $\mathrm{td}$ \\
$\mathrm{CaO}(\%)$ & 0,02 & 0,01 & $\mathrm{td}$ \\
$\mathrm{MgO}(\%)$ & 0,58 & 0,03 & $\mathrm{td}$ \\
\hline \hline
\end{tabular}

Ket: *= satuan dalam ppm

$\mathrm{td}=$ tidak dianalisis karena menggunakan bahan pati murni (pure analysis) 


\section{Tanah}

Dua jenis tanah yang digunakan dalam penelitian ini. Pertama adalah ultisol yang diambil dari daerah Jasinga, Banten, Jawa Barat. Kedua adalah inceptisol yang diambil dari daerah Karang Jati, Ungaran, Jawa Tengah. Karakteristik tanah disajikan pada Tabel 3.

\section{Aspergillus niger}

Isolat A. niger strain YD 17 diperoleh dari koleksi laboratorium Mikrobiologi, Fakultas Pertanian, Universitas Gadjah Mada.

\section{Pengujian dalam medium cair}

Pengujian dilakukan dalam Erlenmeyer berukuran $250 \mathrm{ml}$ yang berisi $100 \mathrm{ml}$ medium Pikovskaya (Atlas et al., 1984) cair steril yang mengandung $10 \quad$ g. $.^{-1} \quad \mathrm{Ca}_{3} \mathrm{PO}_{4}, \quad 0,5 \quad$ g. $\mathrm{l}^{-1}$ $\left(\mathrm{NH}_{4}\right)_{2} \mathrm{SO}_{4}$, dan $1 \mathrm{mg} . \mathrm{l}^{-1} \mathrm{MnSO}_{4}$ dari Merck; 0,1 g. $\mathrm{l}^{-1} \mathrm{MgSO}_{4 \cdot 7} \mathrm{H}_{2} \mathrm{O}, 1 \mathrm{mg} .1^{-1} \mathrm{FeSO}_{4}$, dan 0,2 g. $1^{-1} \mathrm{KCl}$ dari $\mathrm{BDH}$ Ltd; 0,5 g. $\mathrm{l}^{-1}$ yeast extract dari Oxoid; dan 0,1 g. $1^{-1}$ kloramfenikol dari Sigma.

Pengujian sekresi asam organik dalam medium Pikovskaya cair dilakukan sebanyak empat pengujian. Pengujian pertama dengan memvariasikan tingkat kerapatan inokulum spora A. niger YD 17 yang diinokulasikan, yaitu $10^{5}, 10^{7}$, dan $10^{9}$ cfu.ml $^{-1}$ medium Pengujian kedua serupa dengan pengujia pertama, namun sumber $\mathrm{P}\left(\mathrm{Ca}_{3} \mathrm{PO}_{4}\right)$ digan 1 dengan $\mathrm{FePO}_{4}$ (Merck) sebanyak 10 g.l medium. Pengujian ketiga serupa denga pengujian pertama, namun sumber $\mathrm{P}\left(\mathrm{Ca}_{3} \mathrm{PO}_{4}\right.$ diganti dengan batuan fosfat. Pengujia keempat serupa dengan pengujian ketiga namun sumber karbon (glukosa) digant dengan bahan organik campuran onggok sekam dan pati (BOC) dengan perbandinga 69,5:30:0,5, masing-masing sebanyak 10 g.l medium. Sastro (2001) melaporkan bahw bahan organik campuran onggok, sekam da pati $\quad(69,5: 30: 0,5)$ paling mendukun pertumbuhan $A$. niger YD 17 yan ditumbuhkan dalam medium padat. Tingka kerapatan inokulum $A$. niger YD 17 pad pengujian kedua dan ketiga disesuaikan denga hasil pengujian tahap pertama.

Masing-masing Erlenmeyer yang telal terisi medium Pikovskaya dan diinokulasi $A$ niger YD 17 dan diinkubasi di penggojo Kotterman pada kecepatan 100 rotary pe minute (rpm) pada suhu kamar selama 9 har untuk pengujian pertama dan kedua, da diinkubasi selama 14, 28 dan 42 hari untu pengujian ketiga.

Tabel 3. Karakteristik ultisol dan inceptisol yang digunakan dalam penelitian

\begin{tabular}{|c|c|c|}
\hline Penetapan & Ultisol & Inceptisol \\
\hline pH $\mathrm{H}_{2} \mathrm{O}(1: 2,5)$ & 4,45 & 5,06 \\
\hline C Organik (\%) & 1,10 & 1,07 \\
\hline N-Total $(\%)$ & 0,12 & 0,10 \\
\hline $\mathrm{C} / \mathrm{N}$ & 9,20 & 10,70 \\
\hline $\mathrm{P}$-Bray I $\left(\mathrm{P}_{2} \mathrm{O}_{5}, \mu \mathrm{g} \cdot \mathrm{g}^{-1}\right)$ & 3,60 & - \\
\hline P-Olsen $\left(\mathrm{P}_{2} \mathrm{O}_{5}, \mu \mathrm{g} \cdot \mathrm{g}^{-1}\right)$ & - & 4,10 \\
\hline $\mathrm{P}-\mathrm{HCl} 25 \%\left(\mathrm{P}_{2} \mathrm{O}_{5}, \mathrm{mg} / 100 \mathrm{~g}\right)$ & 7,40 & 44,70 \\
\hline $\mathrm{K}-\mathrm{HCl} 25 \%\left(\mathrm{~K}_{2} \mathrm{O}, \mathrm{mg} / 100 \mathrm{~g}\right)$ & 13,50 & 43,00 \\
\hline Ca-dd $\left(\mathrm{cmol} \cdot \mathrm{kg}^{-1}\right)$ & 0,48 & 3,26 \\
\hline Mg-dd (cmol.kg-1) & 1,49 & 2,23 \\
\hline K-dd (cmol.kg-1) & 0,17 & 0,26 \\
\hline Na-dd (cmol.kg $\left.{ }^{-1}\right)$ & 0,03 & 0,08 \\
\hline Al-dd $\left(\mathrm{cmol} \mathrm{kg}^{-1}\right)$ & 17,98 & 0,26 \\
\hline H-dd $\left(\right.$ mol. $\left.\mathrm{kg}^{-1}\right)$ & 9,52 & 0,09 \\
\hline Tekstur Tanah & Lempungan & Lempungan \\
\hline
\end{tabular}




\section{Pengujian dalam tanah}

Pengujian sekresi asam organik oleh $A$. niger YD 17 dalam tanah dilakukan dalam Erlenmeyer $250 \mathrm{ml}$ yang telah terisi 100 gram contoh tanah kering angin lolos saringan berukuran lubang $2 \mathrm{~mm}$. Setiap Erlenmeyer diberi batuan fosfat dan BOC, masing-masing sebanyak $10 \mathrm{~g}$. Tanah, batuan fosfat, dan bahan organik diaduk hingga merata, ditambah air bebas ion hingga $60 \%$ water holding capacity (WHC), dan selanjutnya disterilisasi dalam autoklaf SMIL model WS2-84-64 pada suhu $121^{\circ} \mathrm{C}$ selama 15 menit tiga kali berturut-turut dengan interval waktu 24 jam.

Sebagian dari Erlenmeyer yang berisi campuran tanah, batuan fosfat, dan bahan organik tersebut diinokulasi spora A. niger YD 17 hingga kerapatannya mencapai $10^{7} \mathrm{cfu}^{-1}$ tanah dan sebagian yang lain tidak diinokulasi sebagai kontrol. Erlenmeyer yang berisi campuran tanah, batuan fosfat, dan bahan organik diinkubasi pada suhu kamar selama 14, 28, dan 42 hari. Selama inkubasi kadar air tanah dipertahankan $60 \%$ WHC dengan cara memberikan sejumlah air bebas ion steril menggunakan metode penimbangan.

\section{Persiapan cuplikan analisis}

Persiapan cuplikan analisis asam organik dalam medium cair dilakukan dengan mensentrifugasi medium untuk pertumbuhan mengunakan sentrifus IECCentra-4Bcentrifuge 8000 rpm selama 10 menit, dan disaring menggunakan kertas saring nitroselulosa 0,2 $\mu \mathrm{m}$.

Persiapan cuplikan analisis asam organik dalam tanah dilakukan dengan cara mengekstraksi 1 gram tanah lembab menggunakan 2,5 $\mathrm{ml} 0,1 \mathrm{M} \mathrm{HCl}$ (Merck), digojog di penggojog Kotterman 100 rpm selama 10 menit dan disentrifugasi $8000 \mathrm{rpm}$ selama 10 menit. Supernatan disaring menggunakan kertas saring nitroselulosa 0,2 um (Bolan et al., 1994 and 1997).

\section{Pengukuran asam organik}

Jenis dan jumlah asam organik ditentukan menggunakan high performance liquid chromatography (HPLC) Hitachi 4200 UV/VIS dengan menggunakan kolom C-18 (octadecyl silica 224; 220 x 4,6 mm). Sebanyak $20 \mu$ filtrat dimasukan ke dalam kolom kromatografi dan dielusi menggunakan 0,013 $\mathrm{N} \mathrm{H}_{2} \mathrm{SO}_{4}$ (Merck) dengan kecepatan alir (flow rate) 0,4 ml per menit, selama 20 menit pada suhu $20^{\circ} \mathrm{C}$ (Bolan et al., 1994 and 1997). Jenis asam organik ditentukan dengan membandingkan waktu retensinya dengan waktu retensi standar, meliputi asam sitrat (BDH Ltd.), malat, format, oksalat, dan suksinat (Wakopure).

\section{Hasil dan Pembahasan}

\section{Sekresi asam organik oleh $A$. niger YD 17 dalam medium Pikovskaya}

Hasil pengujian menunjukkan bahwa tingkat kerapatan inokulum A. niger YD 17 yang diinokulasikan dalam medium Pikovskaya cair berpengaruh terhadap jumlah asam organik yang disekresikannya. Semakin tinggi jumlah inokulum, maka jumlah asam organik yang disekresikan cenderung semakin kecil (Gambar 1). Jumlah asam organik yang disekresikan A. niger YD 17 pada perlakuan kerapatan inokulum $10^{5}, 10^{7}$, dan $10^{9} \mathrm{cfu}^{-1} \mathrm{ml}^{-1}$ medium, berturut-turut adalah 55,6, 45,2, dan 42,0 $\mu \mathrm{g} \cdot \mathrm{ml}^{-1}$ medium.

Kecenderungan penurunan jumlah asam organik yang disekresikan tersebut disebabkan adanya peningkatan kebutuhan karbon akibat adanya peningkatan jumlah A. niger. Asamasam organik yang disekresikan oleh mikroorganisme merupakan produk antara (intermediate). Pada kondisi jumlah karbon yang terbatas, mikroorganisme memperoleh energi dan bahan sel dalam jumlah maksimum dengan mengoksidasi substrat dan mengasimilasinya secara sempurna. Hal demikian akan mengurangi jumlah pembentukan dan sekresi asam organik.

Pada pengujian ini juga terlihat bahwa asam malat mendominasi jenis asam organik yang disekresikan oleh $A$. niger YD 17 dalam medium Pikovskaya cair. Porsentae asam malat, sitrat, dan oksalat terhadap jumlah total asam organik yang disekresikan pada perlakuan tingkat kerapatan inokulum spora $A$. niger YD $1710^{5}, 10^{7}$, dan $10^{9}$ cfu.ml ${ }^{-1}$ medium, 
masing-masing adalah 21,8 , dan $71 \% ; 11,7$, dan $82 \%$; 15, 7, dan $78 \%$.

Berdasarkan hasil pengujian ini dapat disimpulkan bahwa tingkat inokulum dengan kerapatan $10^{5} \mathrm{cfu}^{\mathrm{ml}} \mathrm{l}^{-1}$ medium, paling mendukung sekresi asam organik oleh A. niger YD 17 di medium Pikovskaya cair. Namun demikian, untuk pengujian selanjutnya digunakan kerapatan inokulum sebesar $10^{7}$ cfu. $\mathrm{ml}^{-1}$ medium. Hal tersebut didasarkan pada asumsi bahwa tingkat kerapatan inokulum $10^{7}$ cfu akan lebih mendukung ketahanan dan kemampuan hidupnya apabila digabungkan dengan batuan fosfat dan diaplikasikan dalam tanah.

\section{Sekresi asam organik oleh $A$. niger YD 17 dalam medium Pikovskaya yang mengandung $\mathrm{Fe}_{4} \mathrm{PO}_{4}$}

Selain dalam bentuk ikatan kalsium fosfat (Ca-P), sebagian fosfor dalam batuan fosfat juga berikatan dengan unsur besi $(\mathrm{Fe})$ membentuk ikatan besi-fosfat (Fe-P) (Zapata dan Roy, 2004). Untuk menduga kemampuan mikroorganisme pelarut fosfat dalam melarutkan Fe-P maka perlu juga diuji kemampuan sekresi asam-asam organik oleh $A$ niger YD 17 pada saat digabungkan denga $\mathrm{Fe}-\mathrm{PO}_{4}$.

Pada pengujian inkubasi $A$. niger YD 1' dalam medium Pikovskaya yang mengandun $\mathrm{FePO}_{4}$ sebagai sumber fosfat (Pikovskaya $\mathrm{FePO}_{4}$ ), asam organik yang disekresikan meliputi asam malat $(29,7 \%)$, sitrat $(35,2 \%)$ oksalat $(32,3 \%)$, dan suksinat $(2,8 \%)$ (Gamba 2). Jenis asam organik yang disekresikan dalan medium Pikovskaya-FePO ${ }_{4}$ tersebut serup dengan asam organik yang disekresikan dalan medium Pikovskaya-Ca $\mathrm{PO}_{4}$, namun porsenta masing-masing asam tersebut terhadap jumla asam total dan jumlah asam total yan disekresikan berbeda. Pada mediun Pikovskaya- $\mathrm{Ca}_{3} \mathrm{PO}_{4}$, porsentae asam organil yang disekresikan, meliputi asam malat $80,1 \%$ sitrat $11,1 \%$, dan oksalat $8,8 \%$ (Gambar pada tingkat kerapatan inokulum $10^{7} \mathrm{cfu} . \mathrm{ml}^{-}$ medium). Total asam organik yan disekresikan oleh $A$. niger YD 17 dalan medium Pikovskaya-FePO 4 sebesar 74, $\mu \mathrm{g} . \mathrm{ml}^{-1}$ (Gambar 2), sedangkan dalam mediun Pikovskaya-Ca $\mathrm{PO}_{4}, \quad$ sebesar 45,2 $\mu \mathrm{g} . \mathrm{ml}$ (Gambar 1).

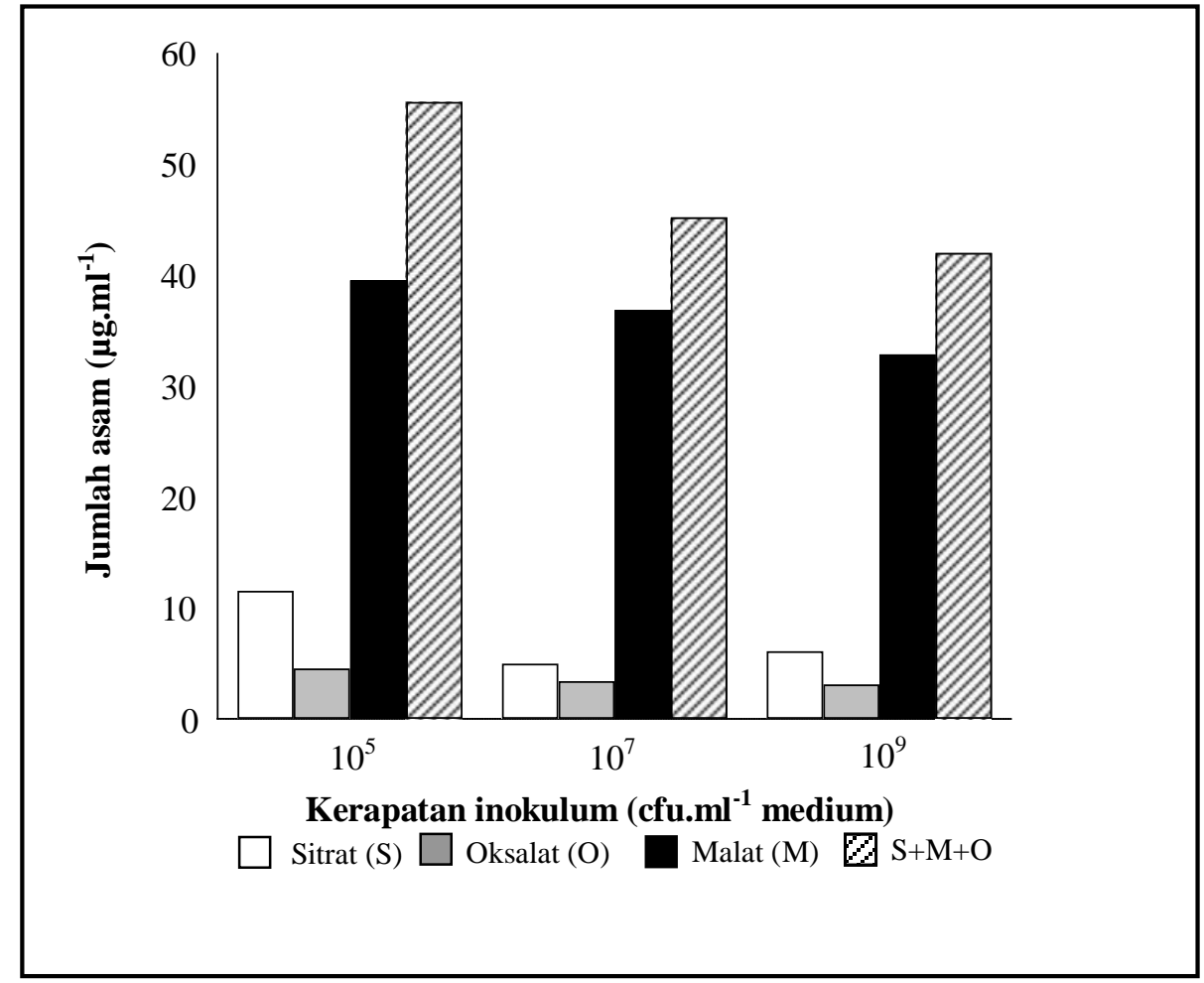

Gambar 1. Sekresi asam-asam organik oleh A. niger YD 17 yang ditumbuhkan dalam medium Pikovskaya cair dengan beberapa tingkat pemberian inokulum 
Perbedaan sekresi asam organik oleh $A$. niger YD 17 dalam kedua medium Pikovskaya yang mengandung sumber $\mathrm{P}$ yang berbeda tersebut disebabkan oleh perbedaan $\mathrm{pH}$ medium dan jumlah logam dalam medium. Pada medium Pikovskaya- $\mathrm{Ca}_{3} \mathrm{PO}_{4}, \mathrm{pH}$ medium pada awal inkubasi mencapai 6,9, sedangkan pada medium Pikovskaya-FePO $\mathrm{P}_{4}, \mathrm{pH}$ medium mencapai 5,7. Selain itu, pada medium Pikovskaya-FePO ${ }_{4}$ mengandung logam $\mathrm{Fe}$ sebanyak 3,701 g. . $^{-1}$, sedangkan pada medium Pikovskaya $\mathrm{Ca}_{3} \mathrm{PO}_{4}$ hanya mengandung $\mathrm{Fe}$ sebanyak 0,001 g.1 ${ }^{-1}$.

Guebel dan Darias (2001) melaporkan bahwa perbedaan kondisi medium, di antaranya $\mathrm{pH}$ dan kandungan logam, akan menyebabkan perubahan akumulasi dan sekresi asam organik oleh $A$. niger. Pada $\mathrm{pH}$ medium mendekati netral $(\mathrm{pH} 7)$, A. niger cenderung akan mensekresikan asam oksalat, sedangkan pada $\mathrm{pH}$ 2,2 hingga 5, A. niger cenderung akan mensekresikan asam sitrat. Ul-Haq, et al., (2002) melaporkan bahwa pada kondisi $\mathrm{pH}$ medium 6,0, sekresi asam sitrat oleh $A$. niger dalam medium tetes tebu mencapai 98,9 g..$^{-1}$, penurunan $\mathrm{pHmediumdibawah}$ 6,0 menurunkan jumlah asam sitrat hingga 52,0 g. . $^{-1}$ medium.

Sementara itu, Scragg (1988) melaporkan bahwa pada medium yang mengandung Fe lebih dari 0,01 mg. $\mathrm{l}^{-1}$ medium, sekresi asam sitrat akan berkurang dan mendorong terbentuknya asam-asam organik lain. Ali, et al., (2002) melaporkan bahwa konsentrasi optimum $\mathrm{Mn}^{2+}$ dalam medium tetes tebu yang paling mendukung sekresi asam sitrat adalah $2 \mathrm{ppm}$, sedangkan dalam medium yang mengandung glukosa adalah 0,1 ppm.

\section{Sekresi asam organik dalam medium Pikovskaya yang mengandung batuan fosfat}

Jenis asam organik yang disekresikan oleh A. niger YD 17 dalam medium Pikovskaya yang mengandung batuan fosfat dan BOC (Pikovskaya-batuan fosfat-BOC), memiliki kesamaan dengan asam organik yang disekresikan dalam medium Pikovskaya yang mengandung batuan fosfat dan glukosa (Pikovskaya-batuan fosfat-glukosa), yaitu asam sitrat, oksalat, dan malat (Gambar 3). Asam malat merupakan jenis asam yang paling banyak disekresikan, diikuti asam sitrat dan oksalat, namun porsentae asam malat yang disekresikan dalam medium Pikovskaya-batuan fosfat-BOC lebih tinggi dibandingkan dalam medium Pikovskaya-batuan fosfat-glukosa.

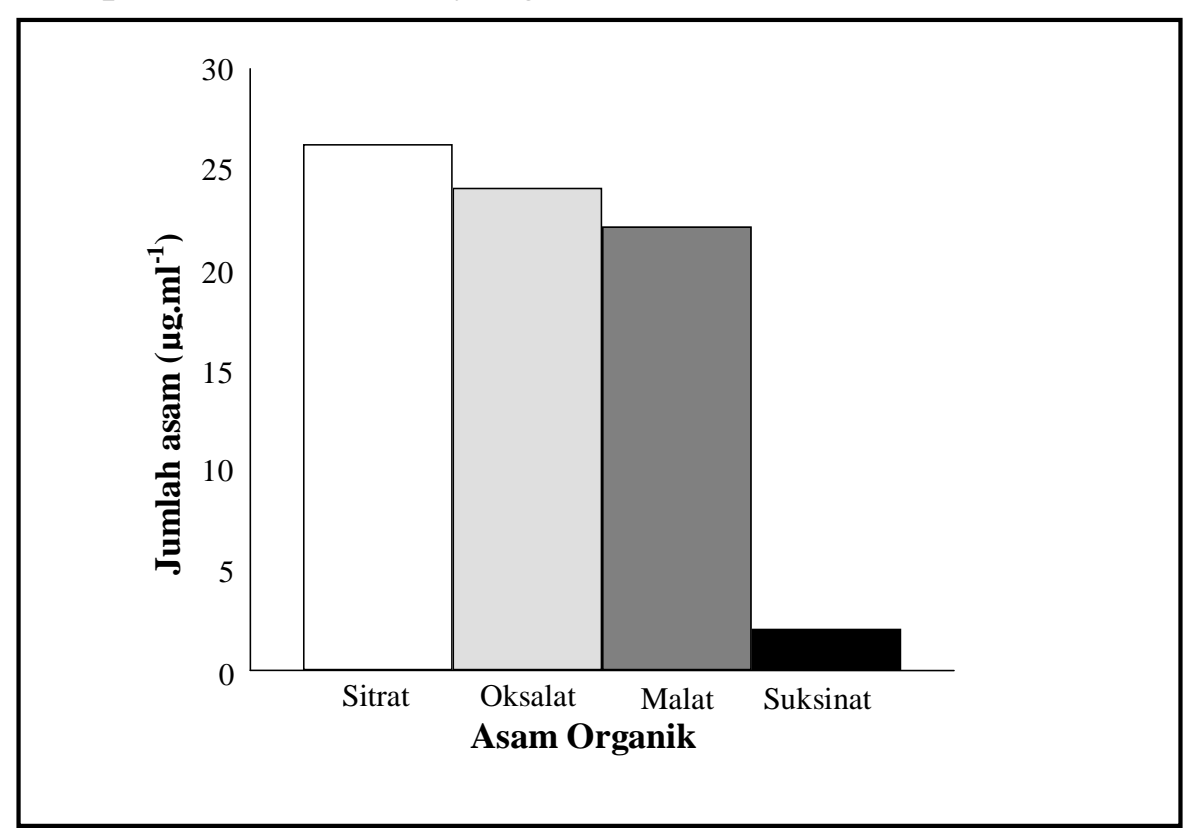

Gambar 2. Sekresi asam-asam organik oleh A. niger YD 17 yang ditumbuhkan dalam medium Pikovskaya cair yang mengandung $\mathrm{FePO}_{4}$ sebagai sumber fosfat. Jumlah $\mathrm{FePO}_{4}(\mathrm{Fe}-\mathrm{P}) 10$ g. $\mathrm{l}^{-1}$ medium, sumber karbon glukosa 15 g. $1^{-1}$ medium, kerapatan inokulum spora A. niger YD $1710^{7}$ cfu. $^{-1}$ medium, inkubasi dilakukan pada penggojog berkecepatan 100 rpm selama 9 hari. 
Jumlah total asam organik dalam medium Pikovskaya-batuan fosfat-glukosa pada 14, 28 dan 42 hari setelah inkubasi, berturut-turut adalah 35,6, 50,5, dan 65,2 $\mu \mathrm{g} . \mathrm{ml}^{-1}$, sedangkan dalam medium Pikovskayabatuan fosfat-BO lebih tinggi, yakni sebesar 145,5, 255,7, dan 181,1 $\mu \mathrm{g} . \mathrm{ml}^{-1}$.

Kesamaan jenis sekresi asam organik pada kedua jenis medium Pikovskaya tersebut di atas, disebabkan oleh kemampuan A. niger YD 17 untuk menggunakan bahan organik campuran onggok, sekam, dan pati sebagai sumber karbon dan energi untuk pertumbuhan dan aktivitas bio-sintesis asam organik. Kemampuan tersebut disebabkan oleh kemampuan $A$. niger YD 17 mensekresikan enzim amilase dan selulase yang mampu merombak struktur bahan organik menjadi glukosa yang selanjutnya digunakan dalam biosintesis asam-asam organik (Sastro, 2001). Menurut Atmodjo (2000) perbedaan kuantitas asam yang disekresikan pada kedua jenis medium tersebut disebabkan oleh perbedaan jumlah karbon dan nutrien yang terkandung dalam masing-masing medium per satuan berat pemberian sumber karbon yang sama. Pada medium Pikovskaya-batuan fosfat-glukosa mengandung 630 mg.l l $^{-1}$ karbon, sedangka pada medium Pikovskaya-batuan fosfat-BC mengandung 657 mg..$^{-1}$ karbon. Pada mediun Pikovskaya-batuan fosfat-bahan organik jug mendapat tambahan beberapa unsur yan berasal dari bahan organik, meliputi $\mathrm{N}, \mathrm{P}, \mathrm{K}$ $\mathrm{Ca}$, dan $\mathrm{Mg}$ (Gambar 3). Unsur-unsur tersebu diperlukan dalam mendukung sekresi asan organik oleh A. niger (Guebel dan Darias 2001).

Sekresi asam organik oleh $A$. niger YI 17 yang digabungkan dengan batua fosfat dalam tanah

Jenis asam organik yang disekresikan $A$ niger YD 17 dalam ultisol dan inceptisol yan diberi batuan fosfat dan bahan organi campuran onggok, sekam, dan pati memilik kesamaan, meliputi asam sitrat dan oksala1 sedangkan asam malat, format dan suksina tidak terdeteksi (Gambar 4). Tingkat sekres asam oksalat oleh $A$. niger YD 17 dalam kedu jenis tanah tersebut lebih tinggi dibandingka asam sitrat, namun pada ultisol porsentae asan sitrat terhadap total jumlah asam yan disekresikan lebih tinggi dibanding inceptisol.

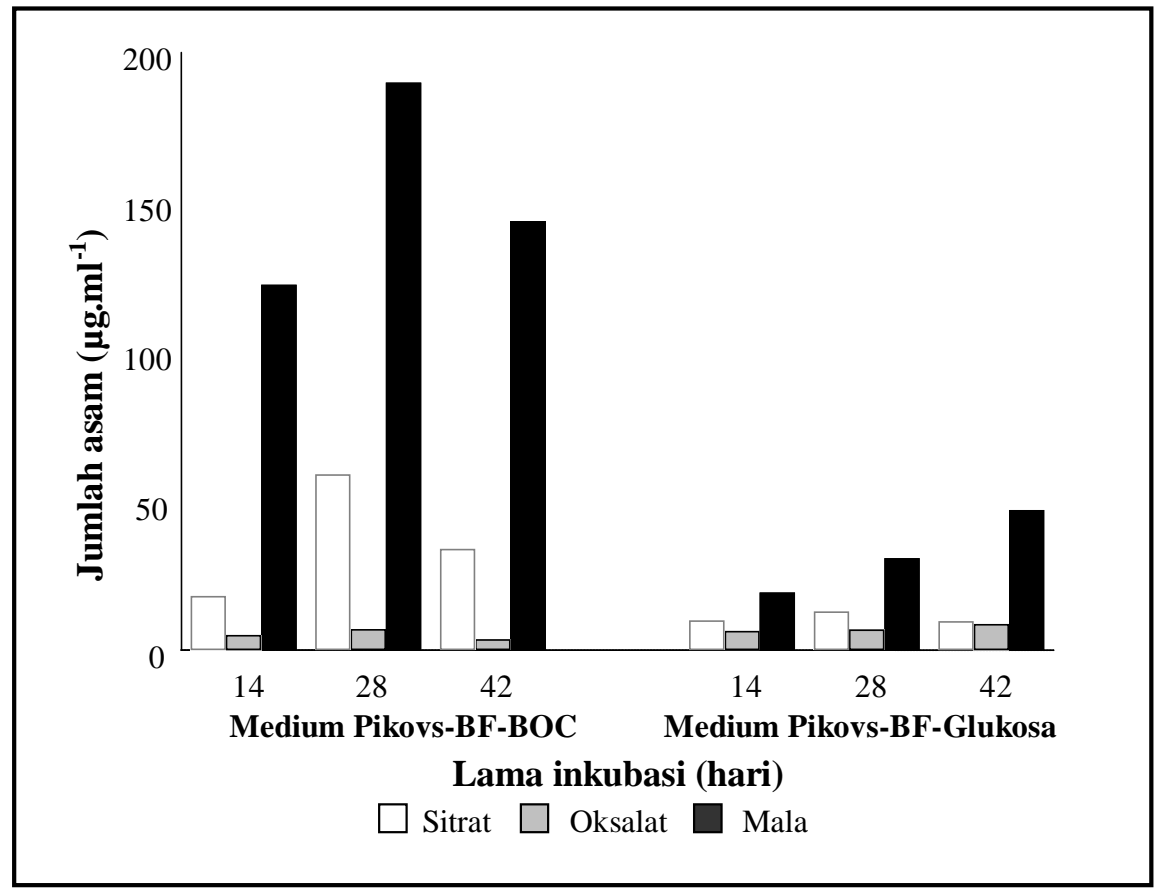

Gambar 3. Sekresi asam-asam organik oleh A. niger YD 17 yang ditumbuhkan dalam medium Pikovskaya-batuan fosfat-BOC dan Pikovskaya-batuan fosfat-glukosa. Jumlah batuan fosfat (BF) dan bahan bahan organik campuran (BOC), masing-masing 10 g. $1^{-1}$ medium, glukosa 15 g. $1^{-1}$ medium, dan kerapatan inokulum spora A. niger YD $1710^{7} \mathrm{cfu}^{-1}$ medium; inkubasi dilakukan pada penggojog berkecepatan $100 \mathrm{rpm}$ selama 14, 28, dan 42 hari. 
Porsentae asam oksalat terhadap total asam organik yang disekresikan dalam ultisol pada 14,28 , dan 42 hari setelah inkubasi, berturut-turut sebesar 92, 58, dan 69\%, sedangkan pada inceptisol berturut-turut sebesar 95, 96, dan $97 \%$.

Total asam organik yang teridentifikasi dalam ultisol pada setiap masa inkubasi sedikit lebih tinggi dibandingkan dalam inceptisol. Total asam organik dalam ultisol pada 14, 28 dan 42 hari setelah inkubasi, berturut-turut sebesar 2460,5, 2587,3 dan 2992,53 $\mu \mathrm{g} . \mathrm{g}^{-1}$ tanah, sedangkan pada inceptisol berturut-turut sebesar 2031,1, 2389,7, dan 2865,5 $\mu \mathrm{g} . \mathrm{g}^{-1}$ tanah. Menurut Sudiana (2004) perbedaan sekresi asam organik pada kedua jenis tanah tersebut disebabkan oleh perbedaan karakteristik tanah, terutama kandungan logam dan $\mathrm{pH}$ tanah (Gambar 4).

\section{Kesimpulan}

Berdasarkan hasil pengujian yang telah diuraikan di atas, disimpulkan bahwa Aspergillus niger YD 17 memiliki kemampuan mensekresikan asam-asam organik pada saat digabungkan dengan batuan fosfat. Jenis asam organik yang disekresikan dalam medium Pikovskaya cair didominasi oleh asam malat, diikuti asam sitrat dan oksalat. Jenis asam organik yang disekresikan dalam tanah didominasi oleh asam oksalat dan diikuti oleh asam sitrat. Sekresi asam organik oleh A niger YD 17 yang digabungkan dengan batuan fosfat dipengaruhi oleh sumber karbon, sumber fosfat, kerapatan inokulum dan karakteristik tanah dan batuan fosfat yang diaplikasikan.

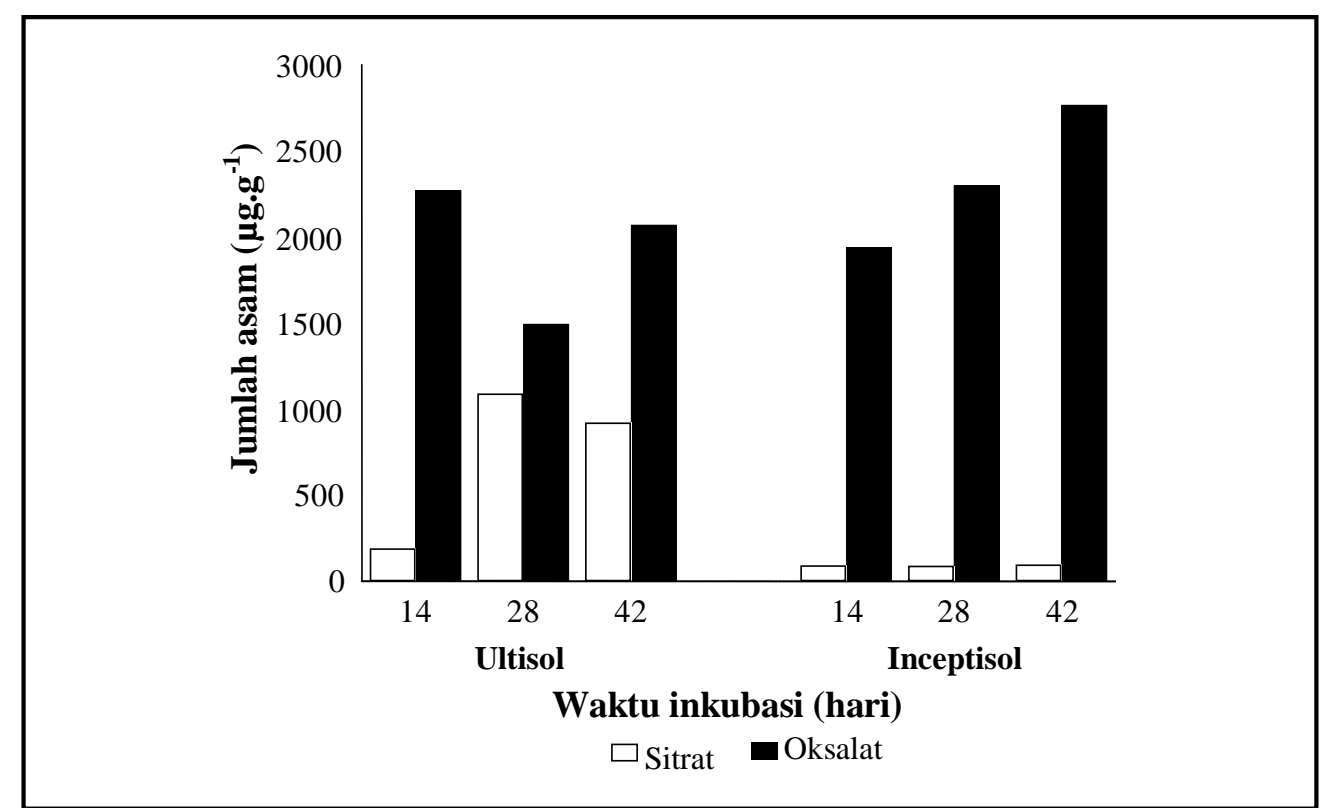

Gambar 4. Sekresi asam-asam organik oleh A. niger dalam ultisol dan inceptisol. Pengujian dilakukan dalam erlenmeyer $250 \mathrm{ml}$ yang berisi tanah $100 \mathrm{~g}$, batuan fosfat $10 \mathrm{~g}$ dan bahan organik campuran onggok, sekam, dan pati, masing-masing 69,5, 30, dan $0,5 \%$ (b/b) sebanyak 10 g. Kelembaban tanah $60 \%$ WHC, diinokulasi spora A. niger $10^{7}$.cfu.g ${ }^{-1}$ tanah, dan diinkubasikan selama 14, 28, dan 42 hari.

\section{Daftar Pustaka}

Ali, S., Ul-Haq, I. and Iqbal, J. 2002. The role of $\mathrm{Mn}^{++}$ ions for high and consistent yield of citric acid in recycling fed-batch bioreactor system and its novelty on kinetic basis. www.ejbbiotechnology.info/content/vol5/PDF 13 Februari 2005.
Atmodjo, K. 2000. Penggunaan Tulang dan Kulit Nanas sebagai Pupuk Organik untuk menumbuhkan Sawi (Brassica juncea L.) Biota V (2) : 63-70

Asmarlaili, Hanafiah, S. dan Oeliem, T.M.H. 1995. Keefektifan mikroorganisme pelarut fosfat yang diisolasi dari berbagai tanah masam di Sumatera Utara. Jurnal Penelitian Pertanian 14(1):11-19. 
Atlas, R.M., Brown, A.E., Dobra, K.W. and Miller, L. 1984. Experimental Microbiology, Fundamental and Applications. Macmillan Publ. Co, New York.

Bolan, N.S., Naidu, R., Mahimairaja, S. and Baskaran, S. 1994. Influence of low-molecular-weight organics acids on the solubilization of phosphates. Biology Fertile Soils 18:311-319.

Bolan, N.S., Elliot, J., Gregg, P.E.H. and Well, S. 1997. Enhanced dissolution of phosphate rocks in the rhizosphere. Biology Fertile Soils 24: 169174.

El-Holi, M.A. and Al-Delaimy, K.S. 2003. Citric acid production from whey with sugars and additives by Aspergillus niger. African Journal of Biotechnology 2(10):356-359.

Ernita. 1998. Uji potensi mikroorganisme pelarut fosfat pada medium pikovskaya. Jurnal Penelitian Pertanian 17:54-58.

Goenadi, D.H. dan Saraswati, R. 1993. Kemampuan melarutkan fosfat dari beberapa isolat fungi pelarut fosfat. Menara Perkebunan 61(3):6166.

Goenadi, D.H. 1996. Pemanfaatan mikroba pelarut fosfat dalam pembuatan pupuk bio-P. Warta Puslit Biotek. Perkebunan II (1): 43-48.

Goenadi, D.H., Pasaribu, R.A., Isroi, Hartono, H. and Misman, R. 1999. Phosphate solubilizing fungi isolated from tropical forest soil. Menara Perkebunan 67 (1): 40-51.

Goenadi, D.H., Siswanto and Sugiarto, Y. 2000. Bioactivation of poorly soluble phosphate rocks with a phosphorus-solubilizing fungus. Soil Science Society of American Journal 64:927-932.

Guebel, D.V. and Darias, N.V.T. 2001. Optimization of the citric acid production by Aspergillus niger through a metabolic flux balance model. www.ejbbiotechnology.info/content/vol4/PDF 27 September 2004.

Legisa, M. and Gradisnik-Grapulin, M. 1995. Sudden substrate dilution induce a higher rate of citric acid production by Apergillus niger. J. Applied and Environmental microbiology 61(7):2732-2736.
Salih, H.M., Yahya, A.I., Abdul-Rahem, A.M. an Munam, B.H. 1989. Availability phosphorus in a calcareous soil treated wit rock phosphate or super phosphate as affecte by phosphate-dissolving fungi. Plant and So 120: 181-185.

Sanjay, K. and Sharma, P. 1994. A highly performanc fermentation process for production of citri acid from sugar-cane molasses. Journal c Microbiology 23:211-217.

Sastro, Y. 2001. Ketahanan Hidup Aspergillus niger pad Batuan Fosfat yang Dipeletkan sert Kemampuan Pelarutannya. Tesis. Prograr Pascasarjana Ilmu Tanah UGM, Yogyakarta.

Scragg, A. 1988. Catabolic pathways in biotecnology fo enginers in Biological System Technological Prosesses. Eds. A.L. Scrag£ Ellis Norwood Limited. Enggland.

Sudiana, I.M. 2004. Isolasi Bakteri Pelarut Fosfat. Biot IX (2): 105-113

Thomas, G.V., Shantaram, M.V. and Sharaswathy, 1985. Occurrence and activity of phosphate solubilizing fungi from coconut plantatio soils. Plant and Soil 87: 357-364.

Ul-Haq, I., Ali, S., Qadeer, M.A. and Iqbal, J. 2002. Citri acid fermentation by mutant strain Aspergillus niger GCMC-7 using molasse based mediun www.ejbbiotechnology.info/content/vol5/PDF 2 Juli 2002.

Widiastuti, H., Goenadi, D.H., Panji, T., Santi, L.P Faturachim, P., Mardiana, N., Harianto, I. an Isroi. 2000. Bioactivation of phosphate roc by indigenous phosphate-solubilizing fung Menara Perkebunan 68 (1): 39-52.

Zapata, F. and Roy, R.N. 2004. The Use of Phosphat Rocks for Sustainable Agriculture. FAC Rome. 